\title{
Determinants of Market Access for Members of Improved Potato Seed Producers' Cooperatives in West Showa Zone, Oromia Regional State, Ethiopia
}

\author{
Tolossa Fufa Gulema
}

\begin{abstract}
This study examined the determinants of market access for members of improved potato seed producers' cooperative in Jeldu District. The specific objectives of the study are to assess the marketing channels of the potato seed, to analyze the factors that affect members to market access, and to identify the market problems potato seed of the sample farmers. Purposive sampling technique was used to select Jeldu district and four primary cooperatives from the sample frame and based on random sampling techniques of probability proportional to the size, 139 sample respondents have been selected. The analysis of the study was based on both primary quantitative data which was collected from the members of the sampled cooperatives through a questionnaire. Data analysis was carried out a logit regression model. Based on the analyses, the main findings of the study revealed that in general majority of the sample cooperatives members (54\%) had access to the market through their cooperative and $46 \%$ of them have not accessed the market through cooperatives the last year. According to the result of the Logit model; storage facility, price, transportation facilities, and quality of seed produced were significant at less than one percent; training and education, and availability of marketing agent were considered significant at less than five percent probability level; and market information and management commitment were significant at less than ten percent probability level. In addition to the above findings, the study also showed that marketing problems of members in the study area were: Infrastructural problems (such as inadequate road facilities, lack of storage facility, lack of transportation truck, high transportation cost), lack of proper and up-to-date market information, price fluctuation, seasonal demands of potatoes seed, poor linkage of members with credit service organizations and quality problems were the major marketing problems included in the study. So, this and other problems related to the members in the study area need to give attention to the concerning government and cooperative bodies.
\end{abstract}

Keywords: Market Access, Cooperative members, Improved Potato Seed, Producers

DOI: $10.7176 / \mathrm{JMCR} / 77-03$

Publication date:March $31^{\text {st }} 2021$

\section{INTRODUCTION}

\subsection{Introduction}

In many countries, farmers' faced challenges of not producing enough food in the context of the rapid rise of the urban and rural non-farming population (Matman and Schrader, 2009 cited by Asfew, 2010) but also face a problem of the possible market for their agricultural products.

However, for most agricultural products, the availability of a market is a major constraint that restricts rural development in developing countries. The question of market access is of crucial importance for developing counties especially for their development agenda, this is attributable to the restricted nature of developing country markets and to the need for the continent to open up to market access to support growth dynamics and efforts to diversify production structures.

Marketing has often been imagined as unproductive or activities of utilization, particularly when the difference between the producer price and the consumer price is significant. The vital cause of this concept is connected to a basic question of economics: which distribution structure will allocate products and services in society most efficiently, getting the right price the major objective in agricultural policies (Gezagn, 2009). A variety of factors can give rise to determine the marketing structure of agricultural products. These aspects may organized in the technical barriers including lack of market information, low quality of the agricultural product, backward market facilities, the large intervention of middlemen, lack of good storage facilities, and others.

Providing farmers with marketing information on time can significantly increase their bargaining power and ability to make good marketing decisions. However, individual farmers have no or little access to market information and thus there is unequal power to negotiate with traders/users. This despite the fact that traders have much better information than farmers have and are thereby in a stronger negotiation position (de Veld, 2004).

As known, the Ethiopian economy is greatly reliant on agriculture which accounts for about half of the GDP. An estimated $85 \%$ of the population gains its livelihood directly or indirectly from agricultural production. However, the agricultural sector is dominated by smallholder farmers holding a land size of less than two hectares and often scattered holding. These farmers are not able to influence the market individually and unable 
to afford an efficient marketing facility (Ayele, 2001).

The development policies of Ethiopia determine agricultural led industrialization for sustainable development of the country to accomplish this strategy stresses technical progress in agriculture and agroprocessing output diversification and better market integration. It determines that for the success of the strategy promoting cooperatives in marketing as one way to change subsistence agriculture to commercial based. Cooperatives are intended to create an efficient agricultural marketing system by providing market information and bargaining power to the farmer.

As a result, it is vital for the socio-economic development of the country that the cooperative sector gets emphasis in the development policies and strategies of Ethiopia that are extended toward poverty alleviation and creating a self-reliant community. Cooperatives are promoted to facilitate the general economic and social improvement of work and living conditions foster self-help activities through mutual help and to popularly participate in general development and employment and income creation through the country and rural communities in particular (Smith 2004).

Cooperative aims at assisting agricultural producers in his effort to dispose of his produce by providing an efficient marketing system. Potato production and post-harvest activities constitute an important source of employment and income in rural areas of developing countries. It has a wide range of uses: as a staple food, cash crop, animal feed, and source of starch for many industrial uses. The crop is preferably appropriate to places where land is limited and labor is abundant, conditions that characterize much of the developing world. Moreover, potatoes are a highly productive crop and produce more food per unit area and per unit time than wheat, rice, and maize reference. Potatoes are becoming increasingly important for developing countries, which, like many other parts of the world, are facing enormous challenges today because of elevated food prices. To increase the performance of production the improved seed should be needed. In general, there are different types of seed producers' organizations, such as private organizations, government organizations, cooperatives, and farmers. The focus of technological support, from research institutions, has been developed to increases the production of the potato seed in a different part of the country.

On the other hand, increasing the scale of selected potato seed production is often stalled by a lack of market. So, the study has assessed the determinants of market access for the members of improved potato seed producers' cooperatives in the Jeldu District.

\subsection{Statement of the Problem}

The low performance of agricultural markets in Ethiopia has been suggested in different studies as the main hindrance toward the growth in the agricultural sector and the overall economy. Elen et.al. (2004) suggested that with an efficient market system, the surplus resulting from increased production benefits neither farmers nor the county

Farmers in Ethiopia are influenced by low producer prices on the one hand and high consumer prices on the other hand. This indicates that the produced amounts of agricultural products were not supported by the access market chain by the reason of different problems. According to Welday (1994), the main problem of the inaccessibility of the market for a farmer is the lack of appropriate transportation facilities and infrastructure services. According to him, transportation costs account for about sixty percent of the marketing cost.

As well known, Ethiopia has possibly the highest potential for potato production of any country in Africa. An estimated $70 \%$ of the country's arable land is potentially suitable for potato cultivation (Yilma, 1991). The majority of this land is enclosed in the Central Highlands (altitude 1,500 - 3,000 meters above sea level) and annual precipitation of $600-1,200$ millimeters (Medhin et. al. 2001). The highland areas of Ethiopia where the potato is normally well suited covers $44 \%$ of the nation's area but includes $88 \%$ of its population and $95 \%$ of its cropped area (Kassie et al. 2010; Grepperud, 1996).

There are four major areas where potato growth in Ethiopia: the central, the eastern, the northwestern, and the southern. These areas cover around $83 \%$ of the potato farmers (CSA 2008/2009). Amongst these areas, Jeldu District is one of the central parts where potato is well suited. In Jeldu district, the production of potato seed increased from time to time due to the adoption of new seeds derived from on-going genetic improvement, disease and insect resistance, drought tolerance, and post-harvest features from research institutes (Holeta Agricultural Research Institute). Even though, farmer's production capacity increases from time to time it are becoming difficult to be accessed farmers to better market in the study area. This might be due to lack of necessary technical and managerial market skills, lack of integration of Secondary/tertiary level cooperatives, lack of access to information, storage problems, imperfections in the marketing chain, and lack of market-related institutions and infrastructure. According to Guenthner (2006), the potato producers in Ethiopia were faced with two main problems, which are production risk and price risk. Production risk is the possibility of low production quality. Weather and pests are the main problems for this. The price risk is the possibility of markets producers are selling at even break prices. These problems have emerged from the lack of access to adequate storage facilities, transportation, and lack of alternative market channels. 
As most of the study indicated the critical obstacle faced by seed duplication programs elsewhere in Ethiopia is the complicatedness of building a consistent seed market. Small quantities of seed are being sold at a profitable prices within the village community. Sales are highest for newly introduced varieties. But most smallscale farmers are unwilling to pay a premium prices to their neighbors for seed they can obtain from their harvests (Rohrbach et al., 2002).

Schmitz (2005) also stated that poor infrastructure, shortage of capital, access to support from business service providers, poor access to information coupled with technology have also contributed to cooperatives to suffer access market.

Additionally, the market of potato seed may be affected by the factors related to the technological, institutional, and socio-economic background of the members. Most members of the cooperatives are not in a condition to take benefit of seasonal price advantage due to low income to cover their financial commitments which in most cases have to settle soon after harvest.

Related to the market access to these improved potato seed producers' cooperatives there has been no study undertaken in the area of identifying the factors that determine the members access to market for their potato seed. Therefore, this study is initiated to assess factors that determine market access for the members of improved potato seed producers' cooperatives, which hold back the development of cooperatives and affect the member's income in the study area. From these evidences the study tried to address

- What are the factors that affect market access of members cooperative?

- How marketing factors, infrastructure factors, instructional factors, economic factors, and demographic factors affect market access for members of improved potato seeds in the study area?

\subsection{Objective of the study}

The overall objective of the study is to investigate the determinants of market access for members of improved potato seed producers' cooperatives in Jeldu District, West Shewa Zone, Oromia Regional State, Ethiopia. The study has the following three specific objectives

1. To identify the determinants of market access for members of improved potato seed producer cooperative in the study area

2. To analyze how marketing factors, infrastructure factors, instructional factors, economic factors, and demographic factors affect the market access for members of improved potato seeds in the study area

This study is organized into five major sections. In the first section overall introduction include statement of the problem, objectives, research question of the study. The second section describes a review of some theoretical and empirical conceptualizations. The third section provides a brief description of the study area and over all methodology used in this study. Section four provides the results and discussion. Final section deals with the conclusion and future research implication.

\section{Literature Review}

\subsection{An Overview of Agricultural Cooperatives}

An agricultural cooperative is an organization of people who join together to engage in the production of agricultural products. It may perhaps increase the productivity and profitability of their farm businesses and then in helping to turn newly formed cooperative and higher cooperative levels to form cooperative tiers into viable businesses operating on sound balance.

Agricultural cooperatives are records in France and Switzerland of cooperatives dairies which were needed because the making of storable cheeses milk had to be pooled from twenty very small farmers. The great grown of the cooperative movement occurred, however in the eighteen and nineteen centuries (Paraiiothayan 1990).

In less developed countries efforts to organize farmers into cooperatives have often failed, even though cooperatives have the likely to supply farm inputs and market farm products that are both important for agricultural development (Siddique, 2015). In developing countries, the choice of economic activities to which priority may be accorded in promoting cooperation ought to be determined by a number of considerations. In the begging, a cooperative is appropriate to be more readily appreciated in the sector of the economy where the large mass of people experiences a high degree of exploitation. It is factors which mainly explain why in many countries credit have been the starting points of cooperative movement (Puri, 1979), the reason for cooperative popularity among farmer simple though cooperative farmers can pool their financial resources and carry out business activities they could not separately perform as efficiently. In some past cases, existing businesses have followed monopolistic profits to the farmer's disadvantages. Therefore the farmers have had significant economic incentives to join together and form cooperatives that operate at cost, thus enabling them to enjoy greater profits from acquiring inputs from receiving services and from marketing outputs (Cobia, 1989). Moreover, the cooperative sector is one of the main partners of the economy (Kumar Soni eta la., 2013) 


\subsection{Role of Cooperatives in Marketing}

Cooperatives enable its members to pool inadequate resources to allow earning ability to meet the need of farmers' farm input and credits improve, market access bargaining power farmers in marketing agricultural products. It estimated about half of global agricultural outputs are marketed through cooperative (UN.2009). In Africa agricultural cooperatives are playing a vital role in provision of market for farmers in rural areas, decreasing transportation costs, and promoting the participation of small farmers in the national and international market.

Furthermore, agricultural cooperatives are farmers' rural institutions through which they have desired to take control over processes for instance farm inputs, marketing of the product, and food processing to add value to the product and also provide farmers with necessary credit to meet members' need. Otherwise, farmers become reliant on intermediaries, merchants who often find it easy to exploit them. Despite agricultural cooperatives helps farmers in increasing their income and contribute to considerable economic development their market share and business volume vary from country to country.

In developing countries, the role of the agricultural cooperative has grown to be a most important economic force and most thriving type of cooperative, measured by market share. In Africa as indicated by Chambo (2009) the most popular agricultural cooperative model has historically been the marketing of agricultural products after the small farmers have individually completed their farm production operations by combining both input distribution and output marketing. As market growth is concerned it is clear that agricultural cooperative has been responsible for introducing the exchange economy in increasable rural areas of Africa. Those cooperative has been accountable for developing modern market in rural areas, were cooperatives provide a ready market for farmers produce, but also absorb transaction costs.

Furthermore, a significant role of expected from agricultural cooperative in developing countries in Africa, and specifically in Ethiopia, however, they have been facing some problems. According to Chambo (2009) among other few are uncivilized management, limited capital resources, inadequate training and education program, poor communication, and participation among members.

\subsection{Potato Seed Production and Marketing System in Ethiopia}

In developing countries including Ethiopia the production of high-grade seed quality of seed have many problems. In Ethiopia many varieties of potato seeds are grown and produced by farmers which are local and selected improved varieties. Several authors classified seed systems into two major types. Formal and informal seed growing system (Struik and Wiersema, 1999 and Endale et al. 2008; World Bank, 2009, Louwaars, 2007 and Almekinders, 1999).

According to Louwaars, (2007), the informal seed growth system covers methods of local seed selection, production, and distribution, while the formal seed systems cover seed production and supply mechanisms operated by public or private sector specialists in different aspects of the seed system, ruled by organized methodologies, with controlled multiplication, and in most cases regulated by national legislation and international standardization methodologies.

The informal seed potato system is a seed potato system in which tubers to be used for planting are produced and distributed by farmers without any regulation.

The informal seed production system is exists in all parts of potato producers areas of Ethiopia. It is the covers major seed potato production system; more than $98 \%$ seed producer in Ethiopia is informal producers (Gildemacher et al. 2009). The role of the formal seed potato system to the overall seed tuber use in Ethiopia is very small as both the private sector and the cooperatives are at the initial stage Hirpa et al. (2010)

The largest challenge countenanced by seed multiplication program in Ethiopia is the complexity of building a sustainable seed market. Small quantities of seed are being profitable sold within the village community. Sales are strongest for newly introduced varieties. But most small-scale farmers are unwilling to pay premium price to their neighbors for seed they can obtain from their own harvests (Rohrbach et al., 2002).

To increase the sales of produced seed by farmers, encouragement actions should be conducted to raise awareness of all farmers in villages under smallholder seed production programs (Kibiby et al., 2001). According to him promotional activities should focus on the advantage of improved seed and the quality of seed produced in their own villages by small holder seed producers. A primary objective of these promotional activities would be to increase the willingness of farmers to purchase seed from small producers.

Another challenge of seed producer farmers in developing countries is the practice of the existing market channel. The choice of the marketing channel depends on several aspects involved in the market. These include access to markets, prices offered in the market, distance to the market,, and the potential of the market to absorb the stock on sale (Montshwe, 2006).

\subsection{Review of Empirical Studies Related to Market Access}

As the study of Amay (2009) on the effect of access to information on farmers' market choice: the case of potato 
in Tiraqui sub water shade. This study identifies power driven transport, availability of paved road, quantity seed, access to credits, access to cell phone and a number of plots are jointly significant the number of market access farmers got.

As study conducted by Daniel (2006) on the performance of primary agricultural cooperatives and determinants of members decision to use as marketing agent in Ethiopia indicated that family size, the price charged, patronage, farmland size, a distance of members from the cooperative to be significantly related to farmers to get market access through cooperative. Similarly, Peter et. al. (2010), studied on determinants of farmers' access to output markets, in Nigeria identified that cost of transport, a distance of farm to market, and influence of cooperative on the marketing of products as the significant factors that affect their access to output markets. This study result shows that the cost of transport negatively affected a farmer's decision to use the market outlet; they found also negative relationship between distance of the farm to the market and their use of markets; however, the influence of the cooperative on the farmer's sales affects their decision positively. Thus, the better the influence of the cooperative, the more likely they are to use the markets. This is possible since the cooperative may provide some service such as transportation at subsidized rates or enhance the market structure to provide a better place for marketing. Thus, most of previous studies suggested that cooperative is the best remedies of farmer market problems in developing countries.

Belete (2008) in his study by using both quantitative and qualitative statistics reported that; number of family, production of size, number of household size, use of fertilizers, patronage refund, and cooperative leadership were significantly affected members to sell their product to the cooperative. This study also indicate that, the major challenges that influence the market performance of cooperatives were lack of capital, poor marketing management of storage and transportation facility, lack of consistent market information, lack of value addition to the product, and the price of the product at required by consumers and customers.

Senyolo et.el, (2009) also indicate that the problems of market access are associated with price risk and uncertainty, complexities of contract enforcement, inefficient numbers of brokers cost of putting small dispersed qualities of products together, and the inability to meet standards. Another challenges regarding to physical market access like physical infrastructure includes roads, market facilities, power, and electricity are the main challenges of market access in Ethiopia. Poor road conditions high costs and distance markets have been influenced as factors that hinder improved market access for emerging farmers, and also contribute toward failing input markets. In their study factors that determine access to input and output markets include distance to markets from producers, the types of available roads, and the transportation costs.

According to Killick et.el. (2000), farmers access to market is influenced by knowledge of detail about the availability of product, quality and price including the frequency, quality and costs of this information; and information about another parties to transactions. Muluken and Workneh (2012), on their study Market access and livelihood diversification in rural areas of Ethiopia, reported that households' access to markets is influenced by location, distance, availability of road infrastructure, and cropping pattern.

Berhanu (2012), in his study of market access and value chain analysis of the dairy industry in Ethiopia: indicated that household size, landholding size, distance to the nearest urban center, and milk yield in liter per day played a significant role in the probability of milk sales market choice. This study result also indicated that the cooperative market outlet was higher for households who had better access to livestock extension services, many years of farming experiences, large landholding size, and members to the cooperative. Compared to accessing individual consumer market outlets, the probability of accessing hotels/restaurants market outlet was higher for households who had better access to livestock extension services and who owned a large number of dairy cows. Therefore, as one can understood from the above empirical literature review cooperative market outlet is more appropriate for alleviate the market access problems farmers in underdeveloped country.

\subsection{Conceptual Framework of the Study}

The explanatory variables indicated in the conceptual framework were selected after going through various literature review given above, which were hypothesized to influence members to access market. Therefore, the here below outlined factors in the conceptual framework are thus the most important and relevant ones for determining the members to market access is categorized as Demographic, Market, socio-economic, infrastructural and Institutional factors as follow. 
Figure 1 Conceptual framework

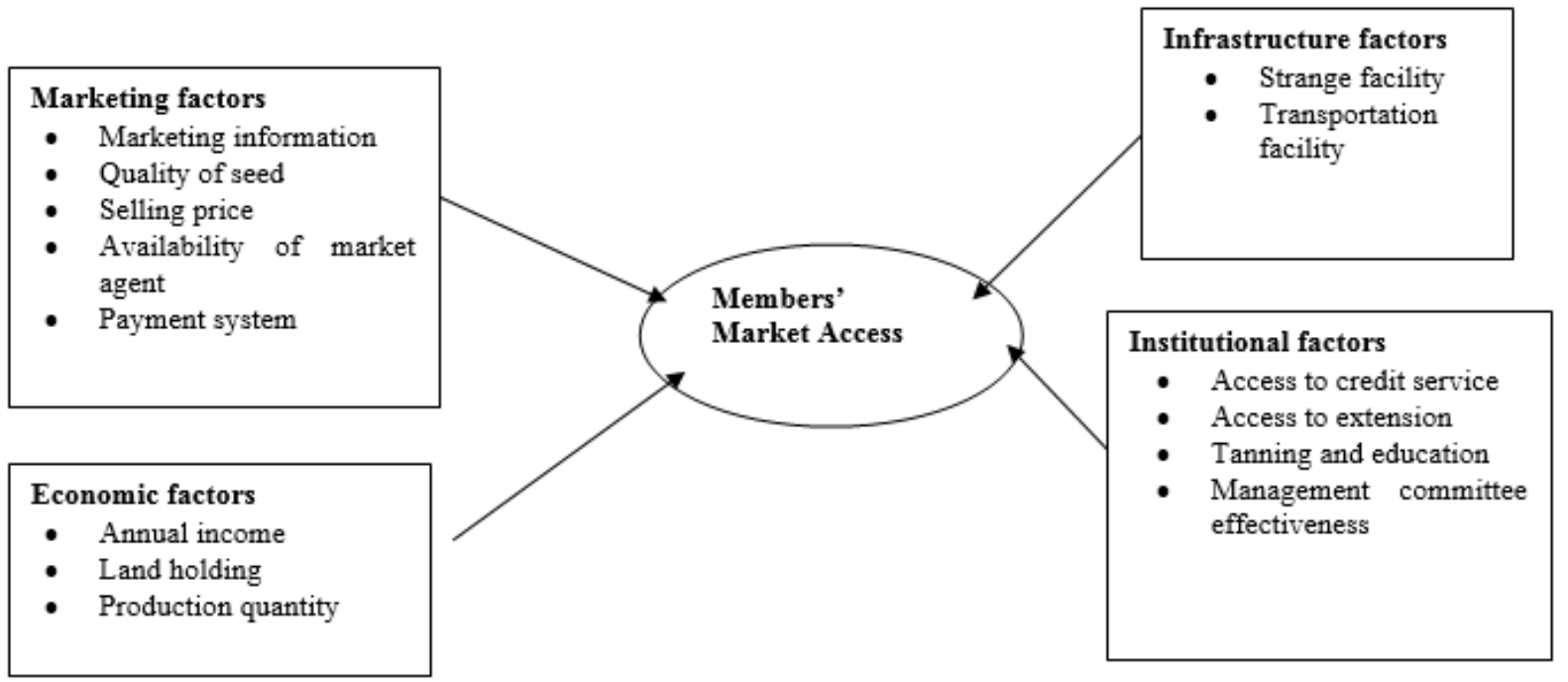

\subsection{Definition of Explanatory Variables}

The study tried to assess the determinants of market access for members of improved potato seed producers' cooperatives in Jeldu district. Though the main variables expected to influence market accessibility for members of improved potato seed producers cooperatives are defined as follows.

Dependent Variable: The dependent variable is members' market access and it is operationalized as the chance to obtain or make use of or take advantage of sell surpluses outputs. It can take advantage of selling surpluses through cooperative or other market outlets. The dependent variable of this study is dummy variable which representing " 1 " if the producers accessed to market through cooperatives and 0 otherwise.

Independent Variables: explanatory variables are variables that proposed to affect the market access on potato seed producers in the study area.

It is very difficult to consider all variables that may affect the market access for improved potato seed production; however, the major variables that affect the market access are considered in the study. The relation, measurements of independent and dependent variables are defined as follows.

Pricing (PRIC). The pricing system is a dummy variable taking value 1 if the cooperative price for potato seed better than other market outlets and 0 otherwise. It is expected that to have a positive effect on market access through cooperatives.

Payment system (PYMSYT). It is a dummy variable that takes a value of 1 if the payment system in cash forms and 0 otherwise. This variable has a positive effect on market access through cooperative if the payment system is in cash.

Availability of other marketing agents (AMKAGT). It is a dummy variable taking a value1 if other marketing agents purchase seed potato in the area of the farmer at a distance less than the cooperative and 0 otherwise. Farmers will get an alternative market outlet to sell their seed if there are other marketing agents in their area. The availability of other marketing agents expected to influence the market access of members by cooperative negatively. The assumption in the study is that if there is another market agent in the area which performs similar activity.

Quantity of seed produced (QNT). Is continuous variable, that total amount of quantity produced in the current year, which is measured by quintal, and expected to affect market access positively. If the quantity of produce is increased at the given year it increases the chance of selling their seed through cooperative being it is the perishable product. As the result of high output, the farmers need favorable market access through their cooperative.

Farm Land size (FLS): is continuous variable and it represents the total area of farmland that individual member of a cooperative owns in hectares. It is implicit that farmers having a larger total area of farmland can produce more products and as a result of the high output of the farmers will need favorable market access. Therefore, it is expected that farm land size will have a positive influence on market access through cooperative.

Annual Income (INCOME) -Members annual income is conterminous variable, refers the average annual income of members. It expected to influence market access positively. As the annual income of an individual increases the probability of individuals keep on the seed in moderate store and keeping the price advantage through cooperative will be high.

Access to market information (AMI) - it is dummy variable that refers the degree of seed producers or members of cooperatives exposure to market information such as price, type of product needed, where it needed, 
and who needs it. It is defined as a value of 1 if households access to market information and 0 otherwise. It is expected to affect the market access for potato seed producers positively.

Seed quality produced (SQLt). It is referring to the physical, physiological, and genetic purity of the seed produced by the members of the selected cooperatives. It is a dummy variable that takes value 1 if the household's seed has quality and 0 otherwise. If the seed has a needed quality it may have a high chance to get market accessibility through cooperative. So it is expected to positively affect the members' market access.

Commitment of Management Committee (COMGTC) - It refers effectiveness of the management committee of the potato seed producers' cooperatives in giving training and education, promoting their seed and in developing marketing strategy for cooperatives. COMGTC is dummy variable taking value of 1 if management committee is committed or 0 otherwise. It is expected to affect the market accessibility positively, if committed management committee is there.

Access to extension service (EXSERV). Extension service is a consultancy given by development agents and other technical persons to farmers. It is a dummy variable taking a value of 1 if the household has exposed to extension service and 0 otherwise. It was hypothesized that the households exposed to extension service will get better accessibility of the market than farmers who did not get the extension services. It is expected to affect positively.

Storage Facilities (STORAGE) - Storage is the place where produced seed is stored until distributed/marketed. It is part of post-harvesting management practice and is also important due to the perishable nature of the potato. The storage facility is a dummy variable and takes values of 1 if the households have a moderate storage facility and 0 otherwise. Therefore, it was hypothesized that the availability of storage facilities affects market access for potato seed producers positively.

Transport Facilities (TRSF). The availabilities of infrastructure or transportation network area important for the movement of products from producers to markets or users.

So the availability of transportation systems is important for the availability of market access. It is a dummy variable that takes a value of 1 if the facilities of transportation for the members are there and 0 otherwise. It is expected to affect the market access of potato seed positively.

Access to credit service (ACCRS). This is a dummy variable that takes a value of 1 if the farmer obtained credit from cooperatives or other microfinance institutions operating in the area, 0 otherwise. The credit helps the farmer in paying the prepayment to the cooperative to get a sufficient amount of fertilizer. It also helps in renting land, constructing storages, and purchasing other inputs that increase production. Therefore, it is expected that this variable would have a positive influence on the marketing of potato seed through the cooperative.

Cooperative Education and training (COPTR). Cooperative organizations are expected to give education and training for their members and awareness for the public as a whole about cooperative benefit so that they improve the marketing position. However, unless they can obtain the required skills through training and education they may face difficulties to understand and apply marketable seed production technology. So those farmers who got training on specific quality seed production technology are more willing than those who didn't get training. It is a dummy variable measured as 1 if farmers got cooperative education and training and 0 otherwise. Therefore, it is expected that the availability of cooperative education and training will affect market access for potato seed positively.

\section{Materials and Methods}

\subsection{An overview of the Study Area}

\subsubsection{Oromia Regional State}

The study is found in Jeldu District West Showa Zone, Oromia Reginal State of Ethiopia. The Oromia Regional

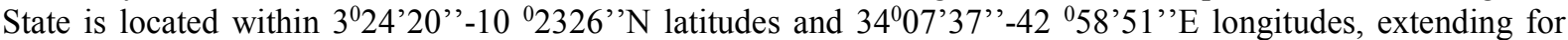
about eight degrees west to east and for about seven degrees north to south or vice versa. Regarding the cooperatives movement, Oromia is one of the largest and most populous of nine regional states and it is the leading in cooperative development in Ethiopia (ILO, 2009). According to the annual report of the Oromia cooperative promotion bureau the cooperative movement has promoted to three tiers from primary to Federation, which operated in the region (OCPB, 2011).

West shewa zone is one of the oromia national regional state zones, it is found between 8017 " north to 90 60 "'north latitude and 37017 ' east to $38045^{\prime}$ " east longitude. It is located in the central part of the regional state, though some part of its areas do inclined to the western part.

On the basis of current border delineation, the zone has an area of $15,185 \mathrm{~km}^{2}$ and it covers $4.15 \%$ of the total area of Oromia regional state. West shewa zone has a total population of 2,071,974 from this 1,831,267 resides in the rural and 242,494 are urban dwellers (BFEDO, 2011).

Jeldu woreda is one of the eighteen districts of the West shewa zone of Oromia regional state. It is located west showa , centeral Ethiopia $\left(9^{\circ} 02^{\prime} 47^{\prime \prime}\right.$ to $9^{\circ} 15^{\prime} 00^{\prime \prime} \mathrm{N}$ and $38^{\circ} 05^{\prime} 00^{\prime \prime}$ to $\left.38^{\circ} 12^{\prime} 16^{\prime \prime} \mathrm{E}\right)$. According to national population census of 2007 the total population was estimated to be 202,655. Agro ecologically Jeldu 
district has altitude of highland 2900 - 3200 above sea level. The land forms of Jeldu district is mountain, plateau, and hill land, and have three types of soil such as nit soil, verity soil and sandy soil which is comfortable for production of various crops. The climate of the area is characterized by bimodal with the main rain season from June to September and short rain season from February to March. Mean annual rainfall is ranging from $1800 \mathrm{~mm}$ to $2200 \mathrm{~mm}$ and the annual average temperate is $19.50 \mathrm{C}$. The most common land use in the study area is mixed crop-livestock system. The types of crops grown in the districts differ in different agro-ecologies. Barley, wheat, potato, faba bean, pea and oil seeds are the major crops grown in the highland part of the districts. In the midland areas wheat and teff are dominant crops followed by sorghum and maize. In the lowlands, the major crops produced include sorghum, maize, teff and oil seeds. Livestock are also an integral part of the farming system in the district.

\subsection{Sample Techniques}

The study area was selected by using purposive sampling techniques from 18 Districts found in West Shoa Zone. Jeldu district is one among the potential areas for potato production in the central Ethiopia, and there is no research conducted before on the related issues. Additionally as compared to many other districts Jeldu district is the front-runner in setting up and association of improved potato seed producers' cooperative in West Showa Zone. Moreover, the District has opportunities of having Holeta Research Institute and Hunde NGO which support the societies by providing improved seed potato and giving training on how to multiply the selected seed. As the result the researcher has been convinced to prefer this district.

In the study area, have a total of seven primary improved potato seed producers' cooperatives societies which form the universe. From the total improved potato seed producers' only four cooperatives that have long year of establishment, and surplus potato seed production was selected as the sample of the study.

To determine the sample size sample respondent was taken from the total population of the sample frame of cooperatives based on the formula given by Kothari (2004).

$$
\mathrm{n}=\frac{\mathbf{Z}^{2 *} \mathbf{p}^{*} \mathbf{q} * \mathbf{N}}{\mathrm{e}^{\mathbf{2}}(\mathbf{N}-\mathbf{1})+\mathbf{Z}^{2 *} \mathbf{p} * \mathbf{q}}
$$

Where: $\mathbf{n}=$ sample size; $\mathbf{z}=95 \%$ confidence limit (interval) under the normal curve that is $1.96 ; \mathrm{p}$ and $q$ are estimated of the proportion of the population to be sample $\mathbf{p}=$ proportion of the population to be included in the sample $(15 \%) ; \mathbf{q}=$ proportion of the population to be not included in the sample $(100-15=85 \%) ; \mathbf{N}=$ size of the population (617); $\mathbf{e}=$ margin of the error or degree of accuracy (acceptable error term) $(5 \%)$

According to this formula, the numbers of respondents are 139. Their selection was conducted by using a random sampling technique by considering its proportionality to the number of members' sample frame of the cooperative.

\subsection{Method of Data Collection}

For this study, both qualitative and quantitative data were employed from both primary and secondary sources based on the sample selected for the study and from other organizations that have directly or indirectly strong relationship to the purpose of the study.

\subsubsection{Primary Data and its collection}

Primary data was collected from members, the management committee of the sample cooperatives, and from the workers of the district promotion office. The data required for analyzing the determinants of market access for the members of improved potato seed producers' cooperatives were collected by administering the questionnaire, interviews and focus group discussions among sample respondents of the selected cooperatives.

Questionnaire:-In order to generate information from the members, a pre-tested and semi-structured questionnaire was used. By this, information from 123 male and 16 female members of the cooperatives about determinants of market access for members of the cooperatives in the study area was collected. Primary data was more concerned with the general demographic character, socio-economic, production, and marketing characteristic of the members and also the institutional characteristic of the selected cooperatives by using semistructured questionnaire

Four enumerators were recruited based on their proficiency in the local language (Afan Oromo), educational background, and prior exposure to data collection. Orientation was given for them on the content of the questionnaire. During data collection, enumerators interviewed the sample farmers using the sum-structured interview schedule; and the researcher was made personal observations and continuous supervision to reduce errors on the spot.

\subsection{Methods of Data Analysis}

\subsubsection{Binary Logistic Regression Model}

3.4.1.1. Specification of Binary Logistic Regression

Logistic regression was employed to empirically identify factors that affect market access of potato seed for data 
collected from sample households. This model is used when the dependent variable is a dummy or binary variable and the explanatory variables are continuous, categorical, or both.

In this study, the dependent variable is a dummy variable which take the value of 1 if the farmers have market access through cooperatives and 0 otherwise. The natures of explanatory variables included in the study were both binary and continuous.

Regarding the dummy dependent variable, there are three different models these are linear regression model, the logit model, and the probit model. The linear regression model is that the outcome variable in this model is binary (Hosmer and Lemeshew, 1989). Besides the difference between the logit and linear regression is reflected both in the choice of parametric models and in the assumption.

The logit and probit models are comparable; but the main difference being that the logistic function has slightly flatter tails that are, the normal curve under the logit function approaches the axes more quickly than in the case of the probit function. In addition that, the probit model is preferable when the response variable is more than two outcomes because the logistic regression model is simpler in estimation than the probit model.

Therefore, a logistic regression model is preferred to study the factors that affect market access for farmers (members of potato producers' cooperative societies).

Before the logistic regression analysis, multi linearity diagnosis or linearity test will be undertaken to filter the highly dependent variables. To see this effect, the presence of high co-linearity was checked for continuous variables using the variance of inflation factor test (VIF) and the contingency coefficient (CC) test will be used for categorical variables. The decision rule for contingency coefficients states that values less than 0.75 mean there is no problem of multicollinearity. When the contingency coefficient approaches 1 , it indicates that there is a problem of multicollinearity between the discrete variables

The study also check the multicollierity problems among variables, As $\mathrm{R}^{2}$ increases towards 1 , it is a collinearity of explanatory variables. The larger the value of VIF, the more troublesome or collinear is the variable Xi. As a rule of thumb if the VIF greater than 10 (this will happen if $\mathrm{R}^{2}$ is greater than 0.8 ) the variable is said to be highly collinear (Gujariti, 2003).

\section{Results and Discussions}

This chapter mainly provides the results and discussion in detail, base on the results obtained from the interview group discussions, and key informants discussion. The results are presented using descriptive statistics such as mean, standard deviation, minimum, maximum, and percentage to assess the marketing channel of potato seed and to identify marketing problems of members in selected potato seed cooperatives of the study area. The Logistic regression model was employed to examine factors that determine market access for members of the seed potato in the study area. The significance of the results was tested by using chi-square and t-test.

\subsection{Logistic Regression Analysis Results}

\subsubsection{Multicollinearity Diagnosis}

The research checked all the hypothesized independent variables for the existence of a multicollinearity problem before running the logistic regression model.

There are two measures that are often suggested to test the existence of multicollinearity. Variance Inflation Factor (VIF) for association between the continuous explanatory variables and Contingency Coefficients (CC) for dummy explanatory variables. The technique of variance inflation factor was working to detect the problem of Multicollinearity between the continuous variables (Maddala, 1992). Based on the result of VIF, the data have no serious problem with multicollinearity due to all variable $\mathrm{R}^{2}$ values are less than 10 . As the result all the 6 explanatory variables were retained and entered into logistic regression model.

Similarly, contingency coefficients were computed to check the existence of multicollinearity problem among the discrete (Dummy) explanatory variables. Accordingly there is no multicollinariy problem among the study variables. The coefficients of all variable are less than 0.7 , which show there is no problem of multicollinearity.

Finally a set of twelve explanatory variables included in the estimation and used in the logistic regression analysis. These variables were selected on the basis of theoretical explanations that how the institutional factors, market factors and economic factors that affect members' market access. To determine the best subset of explanatory variable that are good predictor of dependent variable were estimated by logistic regression using enter method of maximum likelihood with the statistical soft ware program (SPSS version 20.0) in this method all the variables were entered in a single step. Estimates of the parameter of the variables expected to determine members' market access are displayed on the table below. 
4.1.2. Tests of the Goodness Fit of the Model

Table 1. Omnibus Tests of Model Coefficients

\begin{tabular}{lccc} 
& Chi-square & df & Sig. \\
\hline Step & 112.561 & 19 & .000 \\
Block & 112.561 & 19 & .000 \\
\hline & & & \\
\hline Model & $\mathbf{1 1 2 . 5 6 1}$ & $\mathbf{1 9}$ & $\mathbf{0 0 0}$
\end{tabular}

Source: Computed from field survey

Chi-square and Sig. - is the chi-square statistic and its significance level. In this study the statistics for the Step, Model and Block are the same because we have not used stepwise logistic regression or blocking. The value given in the Sig. column is the probability of obtaining the chi-square statistic given that the null hypothesis is true. In other words, this is the probability of obtaining this chi-square statistic (112.561) if there is no effect of the independent variables, taken together, on the dependent variable. This is the p-value, which is compared to a critical value, possibly .05 or .01 to determine if the overall model is statistically significant. In this case, the model is statistically significant because the p-value is 0.000 .

Table 2. Model Summary

\begin{tabular}{lccc}
\hline Step & -2 Log likelihood & Cox \& Snell R & Nagelkerke R Square \\
\hline 1 & $\mathbf{6 6 . 2 6 3}^{\mathrm{a}}$ & & \\
\hline
\end{tabular}

Source: Computed from field survey

Model Summary: Cox and Snell's R-Square attempts to imitate multiple R-Square based on 'likelihood', but its maximum can be less than 1 . Here it is indicating that $59.50 \%$ of the variation in the dependent variable is explained by the logistic model. The Nagelkerke modification that does range from 0 to 1 is a more reliable measure of the relationship. Nagelkerke's $R^{2}$ will normally be higher than the Cox and Snell measure. In this case it is 0.795 , indicating a moderately strong relationship of $79.5 \%$ between the predictors and the prediction.

Table 3. Hosmer and Lemeshow Test

\begin{tabular}{llll}
\hline Step & Chi-square & df & Sig. \\
\hline & & & \\
\hline 1 & 9.702 & 8 & $\mathbf{2 8 7}$ \\
\hline
\end{tabular}

Source: Computed from field survey

Hosmer and Lemeshow test Table is used to accept or reject the null hypothesis. The model does not adequately describe the data. Means that if the significance level is less than 0.05 the null hypothesis is not rejected and the alternative hypothesis which signifies the adequacy of the model to describe the data is rejected. i.e. statistic has a significance of .287 which means that it is not statistically significant and therefore our model is quite a good fit.

Table 4. Classification Table

Observed Predicted

\begin{tabular}{|c|c|c|c|c|}
\hline & & \multicolumn{2}{|c|}{ market access } & \multirow{2}{*}{$\begin{array}{r}\text { Percentage } \\
\text { Correct }\end{array}$} \\
\hline & & Via others & Via coop. & \\
\hline \multirow{2}{*}{\multicolumn{2}{|c|}{$\begin{array}{r}\text { Step } 1 \text { market access No } \\
\text { Yes }\end{array}$}} & 58 & 6 & 90.6 \\
\hline & & 6 & 69 & 92.0 \\
\hline
\end{tabular}

\section{Overall Percentage}

Source: Computed from field survey 
The classification Table is indicates that the overall percent of cases that are correctly or incorrectly predicted by the model. In this case, the full model that classified correctly. As indicated on the table, this percentage has increased from 90.6 for the null model to 91.4 for the full model.

Table.5. Result of Logistic Econometric Model/Variables in the Equation/

\begin{tabular}{|l|l|l|l|l|l|l|}
\hline Explanatory Variables & \multicolumn{1}{|c|}{$\boldsymbol{\beta}$} & S.E. & Wald & $\mathbf{D f}$ & Sig. & Exp(B) \\
\hline FAMILYSIZE & .285 & .547 & .271 & 1 & .603 & 1.329 \\
\hline LANDSIZE & .031 & .666 & .002 & 1 & .963 & 1.032 \\
\hline ACCMINFO & 1.196 & .665 & 3.233 & 1 & $.072^{*}$ & 3.307 \\
\hline SQUALITY & 4.021 & 1.273 & 9.981 & 1 & $.002^{* * *}$ & 55.753 \\
\hline QUANTITY & -.847 & .638 & 1.762 & 1 & .184 & .428 \\
\hline PRSYTM & 3.068 & 1.105 & 7.708 & 1 & $.005^{* * *}$ & 21.504 \\
\hline MNGTEFFEC & 1.279 & .741 & 2.982 & 1 & $.084^{*}$ & 3.593 \\
\hline EXTSERV & 1.145 & .910 & 1.582 & 1 & .209 & .318 \\
\hline STORAGE & 2.551 & .934 & 7.464 & 1 & $.006^{* * *}$ & 12.818 \\
\hline TRPOFACIL & 1.834 & .696 & 6.938 & 1 & $.008^{* * *}$ & 6.257 \\
\hline ACCRED & .496 & .884 & .314 & 1 & .575 & .609 \\
\hline TRAINING & 1.669 & .771 & 4.689 & 1 & $.030^{* *}$ & 5.305 \\
\hline AVMRKAGENT & -1.598 & .688 & 5.391 & 1 & $.020^{* *}$ & .202 \\
\hline
\end{tabular}

Source; computed from field survey results

***,**,* Represent Significant at $1 \%, 5 \%$ and $10 \%$ probability level, respectively

Variables in the Equation Table(5): The variables included in equation are presented. The Wald statistic and associated probabilities provide an index of the significance of each predictor in the equation. The Wald statistic has a chi-square distribution. The simplest way to assess Wald is to take the significance values and if less than 0.10 reject the null hypothesis as the variable does make a significant contribution. The EXP (B) column presents the extent to which raising the corresponding measure by one unit influences the odds ratio. It can interpret in terms of the change in odds. If the value exceeds 1 then the odds of an outcome occurring increase; if the figure is less than 1 , any increase in the predictor leads to a drop in the odds of the outcome occurring. The ' $\beta$ ' values are the logistic coefficients that can be used to create a predictive equation.

\subsection{Discussions}

As displayed on variable in the equation (Table 5) out of the nineteen explanatory variables nine of the variables found to be significant. The other remaining variables were not significant. The effect of these significant variables are interpreted and discussed here under.

Storage facility: This independent variable and member access to market through cooperatives were positively associated and significant at level of $1 \%$ probability level $(0.006, p<.01)$. The Exp $(\beta)$ value signifies that this variable is a useful explanatory variable having positive effect on the market access for the members of the cooperative. That is, an increasing in the availability of members storage facility contribute by a unit increases the likelihood of the member market access through cooperative by a factor of 12.818, if other variables are held constant. This implies that the null hypotheses which state the members who have moderate storage facilities can stay their potato seed until they got better market is not rejected.

Cooperative price for potato seed: Cooperative price influenced the members' to market access through cooperative positively at the significance level $1 \%(.005, \mathrm{p}<0.01)$. Charging competitive price for a quintal of 
farmer's potato seed increases the probability of marketing of potato seed through the cooperative and its intensity by 21.504 . This implies that as there are other marketing agents in the study area purchasing farmers' potato seed, the cooperatives have to charge a competitive price so as to be a marketing agent for the farmers. So that the hypothesis which state price affect the market access through cooperative positively is not rejected. The result was confirmed with the study of Daniel (2006) who reported that price affect member's market participation positively.

Quality: It was positively influence the probability of members' market access through cooperatives. It is significant at 1 percent significance level. As the quality of the potato seed of the farmers increases by one unit, the probability of having market access through cooperative also increase by 55.75 times, if other variables are held constant. This means that members who produce better quality seed could have better access to market through cooperative than the others in the study area.

As a result, the hypothesis which states the more quality of seed, the better the likelihood that it has market access through cooperative, therefore not rejected.

Transportation Facility: The explanatory variable, availability of transportation facility has statistically significant effect on the members access to market through cooperative at the significance level of $1 \%$ and its coefficient (6.257) indicates that being other things are remain constant this explanatory variable affect the dependent variable positively by 6.257 factors. A unit increase of transportation facilities in the members living area, results an increases in the probability of members access to market through its cooperative. This result aligned with the null hypothesis which states the availability of transportation facility contributes to members as they got market access.

Training and Education: As it was expected it is positively correlated and significant by 0.030 at $\mathrm{P}<0.05$ percent probability level related to members access to market through cooperative. This implies that members participated in cooperative training and education programs have developed their knowledge or awareness towards advantages of cooperatives in accessing market. Therefore, knowledge gained through training and education might give chance to the members' access to market through cooperative. The odd ratio of 5.305 for the access to cooperative training and education opportunity shows that with the assumption of the probability of being market access through cooperative increases by a factor of 5.305 as training and education opportunity increased by a unit.

Availability of market agents:- Availability of market agents have statistically significant effect on the member market access through cooperative. Its p-value is $0.020(<0.05)$. This indicates that it has strong association with the member's market access through cooperative. But the value of its odds ratio is 0.203 , which indicates that the association of this variable with the dependent variable is opposite direction, which means availabilities of other market agents affect the members' market access through cooperative negatively. That is, a unit increase in availability of market agents in the members' area causes a decline in probability of members' access to market by its cooperative by a factor of 0.203 . This empirical finding signifies the hypothesis being hypothesized as the two variables have negative association. The result was contradicting with Gachana (2012) study which associated positively with the farmers' access to market.

Management Committee Commitment:- The variable is significant by 0.084 at 10 percent probability level and has positively related with the members' market access through cooperative. As management committee commitments get enthusiastic, members got market access through their cooperative. The effect of this variable indicates that right management of cooperatives' with members' involvement encourages the members to take part in to their cooperatives. The odd ratio of 3.593 for management committee commitment indicates that with the assumption of being members' access to market through cooperative increases by the factor of 3.593 as management commitment level increased by a unit. This empirical finding signifies the hypothesis being hypothesized as the management commitment and market access have positive association.

Market Information: - Market information is the degree of members exposed to general information about the market of his/her products. It means that having the knowledge of where, when, whom and by what price to sell his/her products.

As it was expected this study shows that market information has positive influence on members market access of the sample cooperatives and significant at $10 \%(\mathrm{p}<0.1)$ significance level. It indicates that as the probability of members who got market information increases by a unit, the likelihood of members' access to market also increased by 3.307 times more than that of members who did not got market information. This finding also signifies the hypothesis being hypothesized as the two variables have positive relation.

\section{Conclusion}

The purpose of this study is to examine the determinants of market access for the members of seed potato producers cooperatives of the study area based on the members household survey data. As the study result shows that, the existing marketing channels of the cooperative members were one of the determinants of the market access in potato seed marketing. According to the study $46 \%$ of sample respondents have not market access 
through their respective cooperative last year production. From this one can conclude that the cooperatives in the study area did not provide better market access for their members as expected. Means that the sampled cooperatives market performance is low in relation to member's growth and production performance.

The results from the logistic regression econometrics model indicates that among the explanatory variables as factors determining members to market access through cooperatives; storage facility, transportation facility, market information, quality of seed produced, distance from the cooperatives, availability of other market agents, price, and management committee commitment have statistically significant effect on the market access for the members of the improved seed potato producers cooperatives in Jeldu district.

Based on the findings of the study it is possible to conclude that the development and market access needs multifaceted set of situation involving not only limited to production technology and transport infrastructure, however, it needs the harmonization of different activities and services including rural finance, input supply, assembly with different distribution channels, and integrating with different actors. Producers often face unfavorable price because lack of good deal power, high transportation costs, and difficulties meeting quality standards. Despite an increasing recognition of these challenges by many development actors, the practical difficulties of overcoming the obstacles to market access remain significant.

The study result discloses that $46 \%$ of the members of the sample cooperatives did not use their cooperatives in marketing their seed potatoes. At the same time cooperative were not involved effectively in marketing members' produces. Due to these fact members loyalty in selling their produce to the cooperatives found to be not poor.

\subsection{Implication of the study}

The study finding contributed to the growing impact of literature in identifying factors that determine members' market access through cooperatives in different outcome variables. This study finding have a significant contribution to the cooperatives in building know-how and to provide market accessibility for their members by identifying determinants and the main problems. The results of the study also have significant implications for cooperatives organizations that have the responsibility of promoting and strengthening cooperatives. Moreover, the results of the study may help to show the way for researchers who want to carry out further study on the issue.

\subsection{Implications for Further Study}

This study was limited to some areas of determinants of members' to market access in Jeldu district only. Therefore, other researchers could conduct a further study in the same field by stretching the study area for the sake of using the recommendations of the research for seed potato cooperatives found across the country.

\section{Reference}

Abdissa Gemeda,Girma Aboma, V.Hugo and M.Wilfred, 2001. Farmers' maize seed systems in Western Oromia, Ethiopia. Access Provided by ET - Ambo University at 10/05/12 12:27PM GMT

Agency of Ministry of Economic Affairs, 2009. Introduction of a seed potato production system in Ethiopia. Project number 174384. Information available at www.evd.nl. Date of accession: 13/9/2009.

Almekinders, C.J.M, 2000. Increasing the Resilience of the Farmers' seed system through linkage with formal sector, technology and Agrarian Development, Wageningen University, in Targeted Seed Aid and Seed System Intervention, strengthen small-Framers seed Systems in East and central Africa, Kampala, Uganda, $112 \mathrm{p}$.

Almekinders, C.J.M., and N.P. Louwaars. 1999. Farmers' seed production: New approaches

Analysis and and practices, 291. London: Intermediate Technology Publications.

Asfew(2010), Grain Marketing Performance, Problems And Prospects Of Multipurpose Agricultural Cooperatives In East Wollega. M.A.Thesis(Unpublished)Submitted To Ambo University, Ambo Ethiopia.

Berhanu, (2012). Market Access and Value Chain Analysis of Dairy Industry in Ethiopia: The Case of Wolaita Zone. PH.D. Thesis submitted to Haramay University, Haramay, Ethiopia.

Bezabih, E., and Hadera, G., 2007. Constraints and opportunities of horticulture productionand marketing in eastern Ethiopia. Dry Lands Coordination Group Report No 46. Grensen 9b. Norway. 90p challenge of ending rural poverty. Oxford: Oxford University Press for IFAD.

Chambo, (2009). Agricultural cooperatives: Role in food security and rural development.

Cobia I.David. 1989. Cooperatives in agriculture, Newberys. Practice hall career and technology Englewood. cost approach', Cooperative theory: New approaches, vol. 18, pp 87-107.

CSA (Central Statistical Agency of Ethiopia). 2008/2009. Agricultural sample survey: Report on area and production of crops, Addis Ababa, Ethiopia, p 126.

Daniel, 2006, Performance of Primary Agricultural Cooperatives and Ceterminants of Member Decision to Use as Market Agent in Ada liben \& Lume district, Msc Thesis submitted to Haramaya University.

Dawit, A., Abera D., Lemma D., and Chemdo A., 2004. Domestic vegetable seed production and marketing. 
Research Report No 5. EARO, Ethiopia. 17p

Elenei Z. Gebre-Medhin, 2001. Market institutions, transaction costs, and social capital in the Ethiopian grain market. Research Report No 124. International Food Policy Research Institute. USA. 93p.

Embaye kidanu. 2010, Analysis of Better Supply Chain: The Case of Atsbi-Wenberta And Alamataworeda Tigray, Msc Thesis Hramay University, Ethiopia.

Endale, G., W. Gebremedhin, K. Bekele, and B. Lemaga. 2008b. Post harvest management. In Root and tuber crops: The untapped resources, ed. W. Gebremedhin, G. Endale, and B. Lemaga, 113-130. Addis Abeba: Ethiopian Institute of Agricultural Research.

FAO. 2008. Potato World: Africa-International Year of the Potato 2008.

FDRE (Federal Democratic Republic of Ethiopia) 1998, 'Co-operative Societies Proclamation No.147', Negarit Gazeta $29^{\text {th }}$ December, 1998, Addis Ababa, Ethiopia.

Gachena,(2012). Determinants of Farmers' Access to Market in Selected Grain Marketing Cooperatives of Ambo District West Showa Zone, Oromia Regional State. M.A. Thesissubmitted to Ambo University, Ambo Ethiopia (unpublished).

Gebremedhin, W., G. Endale, and B. Lemaga. 2008. Potato variety development. In Root andtuber crops: The untapped resources, ed. W. Gebremedhin, G. Endale, and B. Lemaga,15-32. Addis Abeba: Ethiopian Institute of Agricult ural Research.Geneva.

Getachew, Tesfaye and Awole Mela. 2002. The Role of SHDI in Potato Seed Production in Ethiopia: Experience from Alemaya Integrated Rural Development Project. African Potato Association Conference Proceedings, Vol. 5, pp. 109-112.

Gezahagn(2009), Determinants And Role of Farmers' Seed And Seedling Multiplication in the SNNP Region Seed System. Haramaya University

Gildemacher, P., W. Kaguongo, O. Ortiz, A. Tesfaye, W. Gebremedhin, W.W. Wagoire, R. Kakuhenzire, P. Kinyae, M. Nyongesa, P.C. Struik, and C. Leewis. 2009a. Improving potato production in Kenya, Uganda and Ethiopia. Potato Research 52: 173-205.

Gizachew Getaneh, 2006. Dairy marketing patterns and efficiency: a case study of Ada'a liben district of Oromia region, Ethiopia. An Msc Thesis Presented to the School of Graduate Studies of Alemaya University. 100p

Grepperud, S. 1996. "Population Pressure and Land Degradation: The Case of Ethiopia," Journal of Environmental Economics and Management 30: 18-33.

Guenthner, J.F. 2006. Development of on-farm potato seed tuber production and marketing scheme. Agricultural economics extension series no. 06-01, July 2006. University of Idaho, Moscow.

Gujarati, D.N, 2003. Essential econometrics, second edition, McGraw Hill, pp. 5549-552. New York.

Guluma, D. A. 2020. Factors Affecting Potato (Solanum tuberosum L.) Tuber Seed Quality in Mid and Highlands. International Journal of Agriculture \& Agribusiness ISSN: 2391-3991, Volume 7 Issue 1, page $24-40$

Helm.,F.C(1968). The economics of enterprise, London, university of London press and marketing in eastern Ethiopia. Dry Lands Coordination Group Report No 46. Grensen 9b. Norway. 90p

Hirpa, A. , Miranda P. M. Meuwissen, A. Tesfaye, Willemien J. M. Lommen , Alfons Oude Lansink , A. Tsegaye, Paul C. Struik (2010), Analysis of Seed Potato Systems in Ethiopia.

Horton, D. and Fano, H. 1985, Potato atlas, International Potato Center in rural ethiopia: http://www.eccoinnovation.net.node.113 accessed on 25 July, 2009.

International Fund for Agricultural Development (IFAD). 2001. Rural poverty report: The International labour office.

Jeldu district, 2011 Agricultural Office report, unpublished.

Kassie, M., Zikahli, M. P., Pender, J. and Kohlin, G. 2010. The economics of sustainable land management practices in the Ethiopian Highlands. Journal of Agricultural Economics 61(3): 605-627.

Killick T, Kydd J, Poulton C (2000). Agricultural Liberalization, Commercialization and the Market Access Problem in the Rural Poor and the Wider Economy: The Problem of Market Access, IFAD

Kohls, R, L. and J.N. Uhl, 1985. Marketing of Agricultural Product. Fifth Edition. McMillian Publishing Company, NewYork, USA.

Kohteri, 2004, Research Methodology, fourth edition: new age international (p) limited, publishers 4835/24, ansari road, daryaganj, new Delhi.

Kotler, P., 2003. Marketing Management. Eleventh Edition. Pearson Education Inc, USA.

Kumar Soni \& Harjinder Pal Singh Saluja (2013). A Study On Development Of Cooperative Movement In Planned Economy ANIL International Journal of Economics, Commerce and Research (IJECR) ISSN 22500006 Vol. 3, Issue 1, Mar 2013, 39-48

Louwaars, N. (2007), Seeds of confusion: The impact of policies on seed systems. PhD dissertation, Centre for Genetic Resources, WUR, The Netherlands.

Lynne Reinner Publishers, Boulder, London.. 
Maddala GS. Limited-dependent and qualitative variables in econometrics (No 3). Cambridge: Cambridge University Press; 1992.

Maddala, G.S, 1997.Limited dependant and qualitative variables in Econometrics (Cambridge University press: Cambridge)

Maredia, M, H.Julie and B Duncan, with N.Anwar, W .Mariah and Kei kajia, 1999. Increasing seed system efficiency in Africa; Concepts, Strategies and Issue. MSU, international development working paper, Michigan

Medhin, G.; W. Giorgis; Endale Gebre; Kiflu Bedane; Bekele Kassa. 2001. Country Profile on Potato Production and Utilization: Ethiopia. Ethiopian Agricultural Research Organization (EARO), Holetta Agricultural Research Centre, National Potato Research Program.

Mendoza, G., 1995. A primer on marketing channels and margins.p257-275. In G.J.Scott(eds.).

Monteshwe,B, D, 2006. Factor affecting participation in mainstream cattle market by smallscale cattle farmers in Souse Africa, MSc Thesis, Department of Agricultural Economics, University of Free State ,Bloemfontein. $118 \mathrm{p}$

Mulatu, E., Ibrahim, O. and Bekele, E. 2005, 'Improving Potato Seed Tuber Quality and Producers' Livelihoods in Hararghe, Eastern Ethiopia', Journal of New Seeds, vol. 7, no. 3, pp 31-56.

Muluken Elias and Workneh Negatu (2012), Market Access and livelihood diversification innortheastern Ethiopia. Ethiopian Journal of Economics, EEA vol. 11, no.2.

Ortmann, G. and King, R. 2007, 'Agricultural cooperatives II: Can they facilitate access of small-scale farmers in South Africa to input and product markets?', Agrekon, vol. 46, no. 2, pp 219-244.

Paraiiothayan K. 1990. The Cooperative Movement In The Jaffna District Of Sri Lanka From 1911 To 1970 Institute of Education University of London February 1990

Peter. O. Agbola, Adenaik, Thomas andBabalola D.A (2010), Determinants of farmers' access to output markets and the effects on income; A case study of Ikenne local government area, Nigeria. Journal of life and physical science, acta SATECH 3 (2): $33-39$

Puri O. P. (1979). Cooperative General Science Program. Clark College Atlanta, Georgia U.S.A.

Schmitz H.(2005)value chain; Prices, Products, and People: Analyzing Agricultural Markets in Developing Countries.

Senyolo G.M, Chaminuka, Makhura M. N. and Belete A 2009. Patterns of access and utilization of output markets by emerging farmers in South Africa: Factor analysis approach. African Journal of Agricultural Research Vol. 4 (3), pp. 208-214.

Siddique, 2015. The Role of Cooperative Society for Marketing Agriculture Producs in Bangladesh Global Journal of Management and Business Research: E Marketing Volume 15 Issue 5 Version 1.0

Singh P., Ravi P. Singh, Kumar.M. S , and Mohapatra C (2014). Quality Seed Production, Its Testing And Certification Standard. Publisher: Mewar Institute of Management, Sec-4C, Vasundhra, GZB.

Solomon, 2002. Performance of cattle marketing in southern Ethiopia with special emphasis on borana zone. Unpublished

Staatz, J. 1987, 'Farmers' incentives to take collective action via cooperatives: A transaction

Sthapit, B., R. Ram, C. Pashupati, B. Bimal, and S. Pratap, 2008. Informal seed systems and on-farm conservation of local varieties. In: Farmers, seeds and varieties: supporting informal seed supply in Ethiopia.

Techane Adugna, 2002. Determinants of fertilizer adoption in Ethiopia: the case of major cereal producing areas, M.Sc. Thesis, Agricultural Economics, Alemaya University, Ethiopia.

Teferi Wondale, 2003. Trends in and determinants of fertilizer use in Gozamin woreda, Amhara region, M.Sc. Thesis, Agricultural Economics, Alemaya University, Ethiopia.

Tesfaye,A.B., K. Bedane, C. Yirga, and W. Gebremedhin. 2008. Socioeconomics and technology transfer. In Root and tuber crops: The untapped resources, ed. W. Gebremedhin, G. Endale, and B. Lemaga, 131-152. Add is Abeba: Ethiopian Institute of Agricultural Research.

The Technical Centre for Agricultural and Rural Cooperation (CTA),2008 (http://ruralradio.cta.int/).

Weinberger, K., and T.A. Lumpkin, 2005. Horticulture for poverty alleviation. The unfunded revolution. AVRDC Working Paper No 15. The World Vegetable Center. p19-45

Wiersema, S.G. and R.H. Booth, 1999. Influence of growing and storage conditions on the subsequent performance of seed potatoes under short-day conditions. Potato Res., 28: 15-25.

World Bank, 2007. World Development Report 2008. World Bank, Washington, DC

Yacob (2003), supply chain management and market performance of the banana industry in Eretri, University of free state.

Yilma, S. 1991. The Potentials of True Potato Seed in Potato Production in Ethiopia. Actae Horticultrae 270: 389-31 